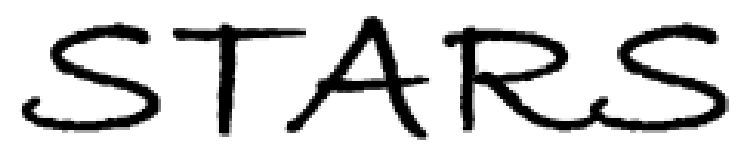

University of Central Florida

STARS

Faculty Scholarship and Creative Works

$5-17-2010$

\title{
Ecotourists' Loyalty: Will They Tell About the Destination or Will They Return?
}

\author{
Manuel Antonio Rivera \\ University of Central Florida, manuel.rivera@ucf.edu \\ Robertico R. Croes \\ University of Central Florida, robertico.croes@ucf.edu
}

Part of the Hospitality Administration and Management Commons, and the Tourism and Travel Commons

Find similar works at: https://stars.library.ucf.edu/ucfscholar

University of Central Florida Libraries http://library.ucf.edu

This Paper is brought to you for free and open access by STARS. It has been accepted for inclusion in Faculty Scholarship and Creative Works by an authorized administrator of STARS. For more information, please contact STARS@ucf.edu.

\section{Original Citation}

Rivera, M. \& Croes, R. (2010). Ecotourists' loyalty: Will they tell about the destination or will they return? Journal of Ecotourism. 9(2), 85-103.

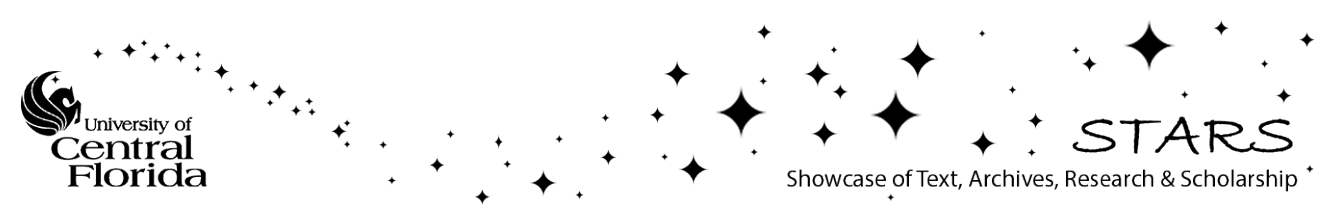




\title{
Ecotourists' Loyalty: \\ Will they tell about the destination or will they return?
}

\begin{abstract}
The objective of this study is to investigate the impact of price, value, satisfaction, quality, and performance on the loyalty of ecotourists toward the destination. By using an attitudinal approach, the study conceptualizes loyalty by analyzing the post-purchase decision-making of the ecotourists (i.e., their intent to return to, or recommend, the destination). The analysis is based on 454 on-site surveys collected from ecotourists visiting the Galapagos Islands in Ecuador. The results from the path analysis indicate that ecotourists are unlikely to return but are willing to recommend the destination. The findings suggest that the Galapagos Islands may be perceived as an iconic destination and considered a "once in a lifetime experience". The loyalty of ecotourists to the Galapagos is reflected only by their willingness to recommend the destination. The article concludes with recommendations for tourism and government organizations regarding the management of word of mouth (WOM) communications and first time visitors in an attempt to improve sustainability.
\end{abstract}

Key Words: ecotourists, Galapagos Islands, behavioral intentions, customer satisfaction, word of mouth (WOM) 


\section{INTRODUCTION}

Since the 1990's, ecotourism has been growing at a rate of 20 to $34 \%$ annually, faster than the tourism industry as a whole, especially in international markets (International Ecotourism Society, 2006). The World Tourism Organization (2001) estimated that 40-60\% of international tourists are nature tourists, with 20-40\% of these considered wildlife-related tourists. According to the United Nations' Environmental Program, this marked growth is occurring around the world's remaining natural areas, especially in less developed countries that are seeking to take advantage of their natural resources in an attempt to increase their foreign currency income. Furthermore, by 2024, the number of travelers taking ecotourism holidays is expected to grow three times faster than those choosing mainstream trips, and is predicted to make up five per cent of the global holiday travelers (Starmer-Smith, 2004). These developments seem to reflect a growing trend towards "environmentalism" or an "environmental movement" (Lee, 1997; Fennell, 2003). The tourists' desire for greater individuality, activity, and flexibility when planning a vacation has increased the demand for ecotourism products (Saarinen, 2005).

Despite this predicted growth of ecotourism, defining its subject, namely the "ecotourist" is complex. The term "ecotourism" was first coined by Ceballos-Lascurain (1987), who defined it as "Traveling to relatively undisturbed or uncontaminated natural areas with the specific objective of studying, admiring, and enjoying the scenery and its wild plants and animals, as well as any existing cultural manifestations (both past and present) found in these areas". Since then, many researchers have attempted to define, conceptualize, and operationalize ecotourism (Blamey, 1997; Donohoe \& Needham, 2006; Fennell, 2001). Generally, an ecotourism site is expected to display four specific dimensions: it is nature-based, environmentally educated, conservation-supporting, and sustainably-managed (Buckley, 1994). The International Ecotourism Society (2007), emphasizes the fact that ecotourism is about connecting conservation, communities, and sustainable travel, thus indicating that those who implement and participate in responsible tourism activities should be guided by 6 ecotourism principles: (1) minimize impacts, (2) build environmental and cultural awareness and respect, (3) provide positive experiences for both visitors and hosts, (4) provide direct financial benefits for conservation, (5) provide financial benefits and empowerment for local people, and (6) raise sensitivity to the host countries' political, environmental, and social climates.

Although the underlying goal behind these principles is to promote responsible travel to natural areas, while conserving the environment and improving the well-being of local people, it may seem unrealistic unless a demand for such experiences exists. For the purpose of our discussion, this study labels ecotourists as those who select to travel to a destination that provides nature-oriented experiences in a pristine natural environment (Eagles, 1992). These particular individuals travel with the intent to observe, experience, and learn about nature. In their definition Eagles \& Cascagnette (1995) put forward the notion that ecotourism can be seen as another act of consumption. In the experience, the ecotourists legitimize the act while searching for change and relaxation (Ryan et al, 2000), thus demonstrating that most ecotourists are not anthropologists, botanists, or even scientists (McKercher, 1993). Furthermore, the ecotourist's outings appear to be motivated by hedonic experiences rather than by environmental and social values (Chan, 2007; Chan and Bum, 2007; Sharpley, 2006). 
Consequently, tourism organizations, both private and public, need to carefully plan the availability of quality and consistent experiences and realize that ecotourists play an integral part in the development of destinations. According to Backman et al, (2001), integrated planning is an essential component for the success of ecotourism. The integrated systems' model for development suggests taking into consideration the impacts that a management decision may have on the ability to deliver the experience the ecotourists seek. Ecotourists are motivated by the desire to escape or relax, see nature, and socialize with friends (Wight, 2001). Neglecting to recognize and understand the benefits sought by visitors is likely to result in a less than satisfactory experience. Failure to satisfy the needs of the ecotourist might also affect the likelihood of their returning to the destination and/or recommending to others.

This suggests that ecotourism and conventional tourism development rely on similar market structures (Duffy, 2002). Assessing the demand for the product and the tourist's preferences will grant access to identifying gaps in the supply (Wight, 1997). The availability of information about shifting tourist preferences will then benefit communities and the environment by matching the supply of products. Sustainable ecotourism is presumed to help in the creation of wealth for the host communities, by stimulating local ownership and encouraging the patronage of locally owned businesses, thus making integrated planning an essential component in the success of ecotourism development (Sirikaya, 1997). However, the success of these destinations will be determined by their ability to simultaneously expand while improving conservation. It should be noted, however, that any form of tourism development is bound to create some impact, thus expectations of "Zero Impact" might be somewhat unrealistic (Kahn, 1997). The longevity and sustainability of ecotourism is highly dependent on the enterprises' ability to carry on as financially sustainable business (Weaver, 2001). This implies that destinations aiming at sustainability would be better off by increasing their understanding of market dynamics. The inability to do so could result in fewer visitors and in even fewer returning visitors (McKercher, 1998; Weaver, 2001).

The importance of high levels of visitor satisfaction, as a driver of tourism demand, suggests that conducting attitudinal surveys, determining needs' assessments, and understanding social impacts are critical for natural resource management organizations (Backman et al, 2001). The ecotourism literature presents considerable information about management issues, tourist profiles, motivations, and preferred experiences (Boo, 1990; Eagles, 1992; Fennell \& Eagles, 1990; Palacio \& McCool, 1997; William, 1992). However, there is a lack of empirical evidence on the subject of understanding quality and satisfaction (Chan \& Baum, 2007), both of which are crucial factors for the success of ecotourism (Page \& Dowling, 2002). The ecotourists' cognitive assessment of the trip can help determine whether or not they will revisit the destination, or influence the decisions of other potential travelers. Satisfied customers are advantageous for the business and a good word-of-mouth (WOM) will supply a great deal of information, representing a potential source of income and a reduction in advertising costs (Fennel \& Eagles, 1990; Ryel \& Grasse, 1991).

Therefore, this study takes a consumer behavior approach to investigate the post-purchase decision-making process among ecotourists. It uses a causal model to examine consumption and behavioral intentions, by assessing the relationship between the perceptions of price, quality, value, performance and satisfaction of the tourists. It assumes that understanding the decision 
process and the destination's performance helps ecotourism management organizations formulate specific objectives, identify relevant problems, design alternatives, plan activities, and allocate efficiently limited resources (Backman et al, 2001). In the next section we present a review of the literature on the conceptual background of ecotourism consumption, followed by a presentation of the model, study methods, and results. The paper concludes with a discussion of the findings, implications and directions for future research.

\section{CONCEPTUAL BACKGROUND}

\section{Customer loyalty}

The intentions to revisit and to recommend tourist destinations are often perceived as desirable outcomes for these destinations. Taylor (1997) suggested that these outcomes constituted good indices for assessing customer loyalty. As a result, the tourist's disposition to return or recommend to others can consequently increase earnings, and at the same time reduce marketing costs (Opperman, 1997; Opperman, 2000). The concept of loyalty is typically gauged by using behavioral, attitudinal, or composite measurements. Behavioral measurements are based on actual or reported purchasing behavior. Jacoby and Chestnut (1978) divided the latter into five types: brand purchase, purchase proportion, purchase probability, synthesis measures, and miscellaneous measures. These particular measurements of loyalty has been criticized and regarded as arbitrary and simplistic, in the sense that they lack investigating factors that highlight disloyalty (Opperman, 1997).

Other indicators of loyalty, such as attitudinal measurements, also rely on the likelihood that a tourist will recommend a destination to other consumers, and/or his/her intention to return (Yoon \& Uysal, 2005). Day (1969) has been a supporter of attitudinal measures over behavioral measures, further suggesting that the latter does not distinguish between intentionally loyal and spurious loyal and may create measurement and conceptual problems, while attitudinal measurements explain an additional portion of the variance, which behavioral measurements cannot account for (Petrick, 2004). Finally, composite measurements of loyalty include both behavioral and attitudinal aspects. This type of measurement is considered the most comprehensive but not the most practical, due to the fact that it requires lengthy questionnaires; in addition, assigning weight to attitudinal and behavioral components might cause measurement problems (Day, 1969). Given the fact that research on ecotourist loyalty is in short supply, this study adopts an exploratory approach and incorporates attitudinal measurements such as intent to recommend a destination and the tourists' inclination towards revisiting the destination.

Very little is known about ecotourist loyalty to a destination. This concern was voiced by Wall (1993), who posits that "one might expect scientists to return to the areas which they are studying but, in the case of ecotourists of other stripes, the world is their oyster and, having viewed one natural wonder, they may be tempted to witness others elsewhere". This suggests that ecotourism destinations might be forced to continually look for new customers. In the ecotourism literature, very few studies have inquired into the phenomenon of repeat visitations. For example, Ingram and Durst (1989) conducted a survey of nature-oriented tour operators and found that one third of all ecotourists are repeat customers. Meanwhile, Powell and Ham (2008) 
investigated the effect of operational and interpretative services on future behavioral intentions. Their findings from a survey of ecotourists visiting the Galapagos Islands suggest that a targeted interpretive program led to satisfied customers, who were very likely to recommend the destination and go on another trip with the same tour operator. Although these results may possibly support the previous claims about ecotourist loyalty, the causal relationship between the travel experience and loyalty to the destination still needs to be tested.

Numerous studies have theorized about the antecedents of behavioral intentions. For example, Gallarza \& Gil-Saura (2006) studied the relationship between value, satisfaction and loyalty, in order to understand university students travel behavior. Cronin et al (2000) assessed the effect of quality, value, satisfaction on behavioral intentions, while Petrick (2004) analyzed the role of quality, value, and satisfaction in predicting cruise passengers' behavioral intentions. Oh (1999) tested an integrative model of service quality, customer value, and customer satisfaction, in order to understand the customers' post-purchase decision-making process. Since this model appears to possess practical validity as well as interpretative qualities, the current study adopted a similar approach and applied it to ecotourists visiting the Galapagos Islands. The next section presents a review of the literature on the various antecedents of behavioral intentions that are proposed in this study.

\section{Quality and satisfaction}

In the tourism literature, the concepts of quality and satisfaction often get mixed up and are used interchangeably by practitioners and academics. This confusion is attributed to the fact that both constructs are derived from the expectancy-disconfirmation paradigm (Oliver, 1980). Among academics, there is also a continuous debate about the causal relationship between these two constructs. Some researchers argue that satisfaction is an antecedent of quality - a subjective disconfirmation, expectations, and performance of satisfaction all influence the perception of quality (Bitner, 1990; Carman, 1990). Another group of researchers perceive quality as an antecedent of satisfaction (Cronin \& Taylor, 1994; Oh, 1999), and argue that cognitive evaluations precede emotional/affective responses (Oliver, 1997). This study embraces Oliver's examination and considers quality to be an antecedent of satisfaction.

The concept of quality has been widely explored in the marketing and tourism literature. Perceived quality can be seen as the consumer's judgment about superiority or excellence (Parasuraman et al., 1988). The difference between perceived quality and objective quality is that the former is a higher level of abstraction that provides a global assessment which, in turn, recalls an attitude (Zeithalm, 1988). Typically, the concept of quality has been measured by using SERVQUAL. This instrument conceptualizes quality as the difference between expectations and perceptions, but over the years, much criticism has surfaced about its reliability, validity, and variance restriction (Peter, Churchill, \& Brown, 1993). Teas (1994) argued that when using SERVQUAL, subjects might not be able to differentiate among the various types of expectations that are presented.

According to Ayala (1995), ecotourists demand more active vacations that emphasize sightseeing, cater to intellectual and sporting interests, address environmental concerns, and offer

quality natural and cultural heritage-based experiences. The quality of the ecotourists' experience 
depends to some extent to whether their expectations are met or surpassed (Shackley, 1996). For these travelers, the expectations of quality will vary depending on where they are situated within the ecotourism spectrum (Weaver, 2001b). The preferences and expectations of ecotourists will most likely be at odds depending if they are "soft" or "hardcore" ecotoursist. Chances are these two groups will share some similar experiences while visiting a destination, thus making it difficult for operators to differentiate between and produce high quality experience for both groups (Burton, 1998). Therefore, the success of future developments will depend on the development of an ecotourism product with high quality and authenticity.

In the ecotourism literature, much emphasis has been placed on understanding the expectations and perceptions of ecotourism experiences with regards to quality. Chan and Baum (2007) posit that the ecotourist experience is multidimensional, thus indicating that the quality can be conceptualized as the ecotourists' affective responses to their desired social-psychological benefits. The findings suggest that ecotourists place particular emphasis on the ecotourism activities, on the interaction with the site service staff, on socializing with other ecotourists, and on the information gathered during the visit.

In 2003, Kahn and Su developed ECOSERVE by embracing the SERVQUAL model with the intention of measuring quality expectations among ecotourists. The results from her study revealed six service quality dimensions: eco-tangibles, assurance, reliability, responsiveness, empathy, and tangibles (in order of importance). Although ECOSERVE contributes to the advancement of service quality expectations and ecotourism, the scale used does not consider perceptions, thus eliminating the assessment of service quality (service quality increases as perceptions of quality exceed expectations).

Previous research indicates that satisfaction is an indispensable concept in understanding the performance of destinations (Danaher and Arweiler 1996; Pizam, Neumann and Reichel 1978), thus demonstrating that the ecotourist experience can be seen as an important element influencing satisfaction. According to Otto and Ritchei (1996), satisfaction stems from the experiential nature of consumption and involves both perceptions and experiences. Furthermore, satisfying experiences provided in ecotourism may lead to enhancing the visitors' favorable environmental attitudes and thus increase their interest in further ecotourism experiences (Lee \& Moscardo (2005). It has been found that subjective personal reactions and feelings experienced as part of consumption are an essential component of the traveler's evaluation and satisfaction (Otto \&Ritchie, 1996). Because of the redundancy in using subjective and objective disconfirmation, this study will use one-dimensional constructs with subjective measurements to indicate perceived quality and satisfaction (Oh, 1999). In addition, performance measurements will be used as antecedents of quality and satisfaction. The next section illustrates the role and importance of performance measurements to gauge satisfaction, quality, and behavioral intentions.

\section{Perception of performance}

The performance measures refer to attributes that are primarily controlled by a supplier and that are conceptualized as the measure of a provider's output, thus offering assistance for making changes that can lead to stronger behavioral intentions (Baker and Crompton, 2000). The 
relationship between perceptions of performance, quality, satisfaction and behavioral intentions in tourism and hospitality has been extensively investigated (Baloglu, Pekcan, Chen, \& Santos, 2004; Baker \& Crompton, 2000; Oh, 1999). Perceptions of performance are expected to influence behavioral intentions both directly and indirectly through satisfaction, quality, and value (Oh, 1999). According to Cronin and Taylor (1992), perceptions of performance will match more closely the customer evaluations and will influence behavioral intentions more than satisfaction. They also concluded that perceptions are a better predictor of quality than disconfirmation.

This is further supported by Szymanski and Henard (2001) who indicated that direct measurements of performance not only measure disconfirmation but also satisfaction. This means that modeling performance as a separate predictor of satisfaction follows the idea that the greater the ability of the destination to provide customers with what they need want or desire, the more they will be satisfied with it. According to Burton (1998), ecotourism is not only about tourists and their motivations; it relates to the total organization that delivers the experience to the tourist, which involves the industry and the resource management. Therefore, this study uses perception of performance measurements as antecedents of quality, value, satisfaction and behavioral intentions (Oh, 1999).

\section{Price and value}

Ecotourists tend to pay significant amounts of money for the travel experience, and most likely they are doing so to satisfy their personal needs, rather than for the sake of external tourism environment (Sharpley, 2006). Perceptions of price and value are deemed to influence satisfaction, thus allowing for evaluating the rewards and sacrifices related to the actual purchase (Stevens, 1992). Prices can alter the nature of the experience by making it more commercialized and structured; moreover, it can increase the expectation to be entertained (Lindberg, 1998). Although Lindberg and Aylward (1999) revealed that the price for nature-based tourism is inelastic, developing countries are challenged by the degree of local economic linkages reflected in the tourism value chain and the level of local ownership. A lack of linkages may mean that international tour operators will capture a larger proportion of the benefits generated from tourism, leaving very little to the local community. This would compel the local community to engage in more entertainment activities to capture a larger proportion of price increases, thereby compromising the perception of value. Therefore the argument in favor of relating price levels with the experience in protected areas remains important (Deng, King \& Bauer, 2002).

Perceived value has been defined as "the consumer's overall assessment of the utility of a product based on perceptions of what is received and what is given" (Zeithaml, 1988, p. 14). Perceived value is experienced before the purchase, at the moment of purchase, at the time of use, and after use (Sánchez, Callarisa, Rodríguez, \& Moliner, 2006). At the same time the perception of value is considered an important indicator of repurchase intentions (Murphy \& Pritchard, 1997). For the purpose of the current study the authors favor the value-satisfaction link (Cronin et al., 2000), which proposes that satisfaction is more strongly related to future behavior, where value acts as an antecedent to satisfaction judgments. Therefore, perceptions regarding price are considered an antecedent of perceived value (Oh, 1999). 


\section{RESEARCH MODEL}

\section{Research questions}

This study attempts to investigate the behavioral intentions for eco-tourists visiting the Galapagos. Based on the conceptualizations presented above, the hypotheses tested in this research are presented in Table 1. Based on these hypotheses, it is expected that perceptions of performance in the Galapagos exert a positive influence on perceived quality, satisfaction, perceived value, intent to return, and intent to recommend. These variables are all expected to be positively related, under the assumption that high quality and value will generate the intention to return and to recommend. Perceived value is expected to directly explain intent to return and intent to recommend, in addition to its influence on the intent to recommend through customer satisfaction and return intention. Finally, this study also hypothesizes that a tourist's intention to recommend a destination to others will be stronger if he/she intends to return to the destination. The proposed model 1 is demonstrated in Figure 1.

\section{Figure 1. Proposed model of service quality, customer value and satisfaction}

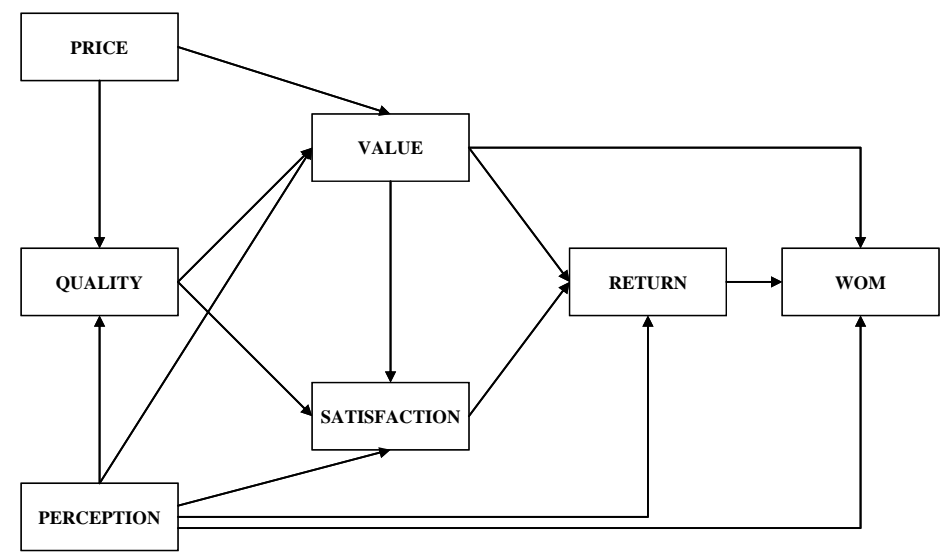

Note: Adopted from Oh (1999)

Table 1. Ecotourist Behavioral Intentions Model

\begin{tabular}{cl}
\hline & \multicolumn{1}{c}{ Perception of performance } \\
\hline Hypothesis $1 a$ & $\begin{array}{l}\text { Perception of performance will be directly related to quality. Higher levels of } \\
\text { performance will result in higher levels of quality. } \\
\text { Perception of performance will be directly related to value. Higher levels of } \\
\text { performance will result in higher levels of value. }\end{array}$ \\
Pypothesis $1 b$ & $\begin{array}{l}\text { Perception of performance will be directly related to satisfaction. Higher levels } \\
\text { of performance will result in higher levels of satisfaction. }\end{array}$ \\
Pypothesis $1 c$ & $\begin{array}{l}\text { Perception of performance will be directly related to intent to return. Higher } \\
\text { levels of performance will result in higher levels of intent to return. }\end{array}$ \\
Perception of performance will be directly related to intent to recommend. & Higher levels of performance will result in higher levels of intent to recommend. \\
\hline Hypothesis $1 e$ & Perception of price \\
\hline Hypothesis $2 b$ & $\begin{array}{l}\text { Perception of price will be directly related to quality. Higher levels of perceived } \\
\text { price will result in higher levels of quality. } \\
\text { Perception of price will be indirectly related with perceived value. Lower levels }\end{array}$
\end{tabular}


of perceived price will result in higher levels of perceived value.

\begin{tabular}{cl}
\hline & \multicolumn{1}{c}{ Quality of service } \\
Hypothesis $3 a$ & $\begin{array}{l}\text { Perception of quality of the services received will be directly related to } \\
\text { perceived value. Higher levels of perceived quality will result in higher levels of } \\
\text { value. } \\
\text { Perception of quality of the services received will be directly related to } \\
\text { satisfaction. Higher levels of perceived quality will result in higher levels of } \\
\text { satisfaction. }\end{array}$ \\
\hline Hypothesis $3 b$ & \multicolumn{1}{c}{ Customer satisfaction } \\
\hline Hypothesis $4 a$ & $\begin{array}{l}\text { Perception of satisfaction will be directly related to intent of return. Higher } \\
\text { levels of satisfaction will result in higher levels intent of return. } \\
\text { Perception of satisfaction will be directly related to intent to recommend. Higher } \\
\text { levels of satisfaction will result in higher levels of intent to recommend. }\end{array}$ \\
\hline Hypothesis $5 a$ & \multicolumn{1}{c}{ Perceived value } \\
Hypothesis $5 b$ & $\begin{array}{l}\text { Perception of value will be directly related to satisfaction. Higher levels of value } \\
\text { will result in higher levels of satisfaction. } \\
\text { Perception of value will be directly related to intent to return. Higher levels of } \\
\text { value will result in higher levels of intent of return. }\end{array}$ \\
Hypothesis $5 c$ & $\begin{array}{l}\text { Perception of value will be directly related to intent to recommend. Higher } \\
\text { levels of value will result in higher levels of intent to recommend. }\end{array}$ \\
\hline Hypothesis $6 a$ & Intent to return \\
\hline Note: Adopted from Oh (1999) & $\begin{array}{l}\text { Intent to return will be directly related with intent to recommend. Higher levels } \\
\text { of intent of return will result in higher levels of intent to recommend. }\end{array}$ \\
\hline
\end{tabular}

\section{Survey Instrument}

To test the proposed hypotheses, primary data relating to visitors to the Galapagos Islands were used. Survey data were collected using an en route methodology. The advantage of this methodology is that it reduces the response error, mainly because the information is sought right after the traveling experience (Otto \& Ritchie, 1996). To ensure heterogeneity, tourists were approached according to the principles of heterogeneous purposive sample (Finn et al, 2000), at various times of a day over a four week period. This technique guarantees heterogeneity, albeit without applying random sample methods. The data was collected from passengers traveling from the Baltra Airport in the Galapagos, departing passengers were asked to voluntarily participate in the survey. Of the 608 tourists who were given the questionnaire a total of 454 $(75 \%)$ were returned with all the questions completed.

The research model presented in Figure 1 was operationalized by using 7 different indicators, all of which were assessed using a six-point Likert scale. The survey instrument measured perceived price using a scale from 1 to 6 (1=very low/6=very high). The overall service quality was measured with a single item. The scale used was anchored with $1=$ much worst than expected and $6=$ better than expected. Customer value was measured by asking tourists to describe the overall value they received as a tradeoff question, "Based on your experience in the Galapagos, please rate the overall value you received for the price you paid", with a similar scale for service quality. The tourists' level of satisfaction was measured using a scale with $1=$ very unsatisfied to $6=$ very satisfied, supporting Oliver's framework (exg. Cronin $\&$ Taylor, 1992). Finally, the intent to return and recommend was measured using an attitudinal approach, with a scale whereby $1=$ very unlikely and $6=$ very likely. The destination perceptions of performance were measured by using nine items related to the travel experience, with 1 
representing the lowest possible score. The nine items were selected from a review of the literature, and following discussions with government officials, tourism service providers, university faculty, and destinations managers in Ecuador.

The proposed model illustrated in Figure 1 was analyzed using AMOS 7 and the variance-covariance matrix of the measured variables as input. This technique enables to simultaneously evaluate multiple regression equations in a single framework. Notably, all direct and indirect relationships in the model are evaluated simultaneously, allowing all the interrelationships among the variables to be assessed in the same decision context.

\section{Study site: the Galapagos Islands}

The Galapagos Islands in Ecuador are considered one of the world's top ecotourist destinations. According to Epler (1993), the rich fauna that inhabits the island cannot be found anywhere else in the world, making the Galapagos one of the most precious ecosystems in the world. As of 2006, this pristine archipelago greeted over 120,000 tourists and tourism has grown at a rate of $14 \%$ per year, for the past 15 years (Epler, 2007). One can notice that over the same number of years, the number of hotels has grown from 33 to 65 and the total number of restaurants and bars, from 31 to 114 (Watkins \& Cruz, 2007). Some believe that this rapid growth in tourism may have caused severe damage to the islands, jeopardizing their status as a UNESCO World Heritage Site (New Scientist, 2007). As previously posited by Williams (2006), this apprehension entails that politicians, scientists, and park managers consider different approached to ecotourism research, in an attempt to understand conservation and to devise ways of dealing with the varied pressures from ecotourism. Therefore, it is clear that an analysis of tourism demands, through understanding the forces that influence ecotourist behavior in the Galapagos, could benefit policy makers in the development of sustainable strategies to conserve this unique sanctuary.

\section{RESULTS}

\section{Sample characteristics}

According to the responses obtained from the survey, the sample consists of $43 \%$ male and $57 \%$ Female. The mean age for the respondents was 51 years, and $95 \%$ were visiting the Galapagos for the first time. A total of 253 tourists or $56 \%$ specified that the main purpose of their trip was ecotourism, while another $35 \%$ came to the Galapagos for leisure or for touring. The tourists seemed highly educated, $70 \%$ of them were college graduates $(32 \%$ had an undergraduate degree and $38 \%$, a graduate degree). Almost $80 \%$ of the respondents reside in the US and Europe $-31 \%$ and $48 \%$ respectively. When making arrangements for their trip to the Galapagos, $75 \%$ of the respondents indicated that they selected a package tour with average trip duration of 5.4 days, staying either in a hotel or on a boat $-55 \%$ and $43 \%$ respectively. Besides visiting the Galapagos, these tourists also visited other destinations such as Peru (10\%) and other cities in Ecuador $(74 \%)$. Close to $50 \%$ or more of the tourists relied on the internet, travel guides and books, or travel agencies to gather information about the Galapagos. On the other hand, travel guides and books were the most popular sources of information while at the destination $(60 \%)$. The complete distribution of information sources used is presented in Table 2. These 
tourists embarked in a variety of activities during their trip. The most popular activities were: hiking, visiting historic sites, scuba diving, craft shopping, bird watching, and visiting Museums or Monuments (see Table 3).

Table 2. Sources of information used before and during the trip

\begin{tabular}{lcc}
\hline Information sources & Before the Trip & During the Trip \\
\hline Internet & $60 \%$ & $19 \%$ \\
Travel guides and books & $51 \%$ & $59 \%$ \\
Travel agency & $49 \%$ & $23 \%$ \\
Tour operators & $36 \%$ & $25 \%$ \\
Friends and family & $34 \%$ & $12 \%$ \\
Local Tourism Office & $13 \%$ & $10 \%$ \\
\hline
\end{tabular}

Table 3. Preferred activities while visiting the Galapagos

\begin{tabular}{lc}
\hline \multicolumn{1}{c}{ Activity } & Percentage (N=454) \\
\hline Hiking & $64 \%$ \\
Visiting historic sites & $54 \%$ \\
Scuba-diving & $53 \%$ \\
Shopping for crafts & $46 \%$ \\
Bird watching & $46 \%$ \\
Museums & $42 \%$ \\
Monuments & $41 \%$ \\
Religious sites & $36 \%$ \\
Artisan sites & $21 \%$ \\
Community visits & $20 \%$ \\
Rock climbing & $6 \%$ \\
Fishing & $3 \%$ \\
\hline
\end{tabular}

Findings

The correlations, means, and standard deviations for all variables are presented in Table 4. Since performance was the only variable measured using the average of nine items, we decided to test consistency and reliability. The internal consistency coefficient for the performance items was 0.87 (see Table 4). The perception items with the lowest scores were accessibility, local environmental quality, easting and drinking places, transportation and accommodations (Table 5). Overall, tourist visiting the Galapagos assigned a higher rating to satisfaction than to any other variable. There was also a significant difference $(\mathrm{p}<.001, \mathrm{df}=453)$ between the tourists intent to return $(M=3.52)$ and their intent to recommend $(M=5.3)$. 
Table 4. Correlation and descriptive results

\begin{tabular}{lcccccccccc}
\hline Variable & $\mathbf{1}$ & $\mathbf{2}$ & $\mathbf{3}$ & $\mathbf{4}$ & $\mathbf{5}$ & $\mathbf{6}$ & $\mathbf{7}$ & $\mathbf{N}$ & Mean & $\begin{array}{c}\text { Std. } \\
\text { Deviation }\end{array}$ \\
\hline Price & 1 & & & & & & & 454 & 4.1 & 1.0 \\
Quality & 0.15 & 1 & & & & & & 454 & 4.7 & 0.9 \\
Value & 0.15 & 0.74 & 1 & & & & & 454 & 4.6 & 0.9 \\
Recommend & 0.13 & 0.49 & 0.43 & 1 & & & & 454 & 5.3 & 0.9 \\
Return & 0.01 & 0.12 & 0.14 & 0.24 & 1 & & & 454 & 3.5 & 1.6 \\
Satisfaction & 0.09 & 0.52 & 0.51 & 0.65 & 0.24 & 1 & & 454 & 5.2 & 0.9 \\
Perception & 0.21 & 0.59 & 0.56 & 0.52 & 0.21 & 0.58 & 1 & 454 & 4.8 & 0.7 \\
\hline
\end{tabular}

Table 5 Descriptive Statistics for Perception of Performance

\begin{tabular}{lcc}
\hline Performance Items & Mean & Std. deviation \\
\hline Hospitality of local community & 5.11 & 0.91 \\
Range of activities & 5.08 & 0.93 \\
Professional service & 5.00 & 0.93 \\
Safety and security & 4.88 & 1.07 \\
Accommodation & 4.83 & 0.98 \\
Transportation & 4.75 & 0.94 \\
Eating and drinking spots & 4.75 & 0.99 \\
Local environmental quality & 4.71 & 1.12 \\
Accessibility & 4.58 & 0.98 \\
\hline Note: Cronbach's Alpha: 0.87 & & \\
\hline
\end{tabular}

For the analysis, fit indices were chosen, following recommendations by $\mathrm{Hu}$ and Bentler (1998). Fit indices included in the current investigation are the Bentler (1989) comparative fit index, or CFI, the Bentler and Bonett (1980) normed fit index, or NFI, and Browne and Cudeck (1993) "root mean square error of approximation", or RMSEA. Both the CFI and NFI may range in value from 1.0 to 0.0 . According to Bentler (1989), a fit index of 0.0 is associated with a "null" model (one specifying that all items are uncorrelated), while a fit index of 1.0 represents a "saturated" model (a model with zero degrees of freedom that perfectly reproduces the original covariance matrix). Values greater than 0.9 indicate a good fit of the data, while values higher than 0.95 indicate an excellent fit of the data. Conversely, an RMSEA value of about 0.08 or less would indicate a reasonable error of approximation.

Results of the proposed model reveal that both the CFI (.992) and NFI (.988) are greater than 0.90 and the RMSEA (.063) are less than .08 , suggesting that the model is a good fit for the data. Therefore, these findings suggest that each item is uniquely related to the factor to which it was assigned. Therefore, the proposed model was tentatively accepted, pending further tests to examine its reliability and validity. The results of the path analysis appear in Figure 2. Anchored on each causal path are the standardized regression coefficient and the explained variance. The amount of variance explained for each variable is expressed as a percentage. As shown in the goodness-of-fit indexes (Table 6), the proposed model demonstrates an excellent fit (Browne \& Cudeck, 1993). 


\section{Figure 2. Model of the variables related to behavioral intentions}

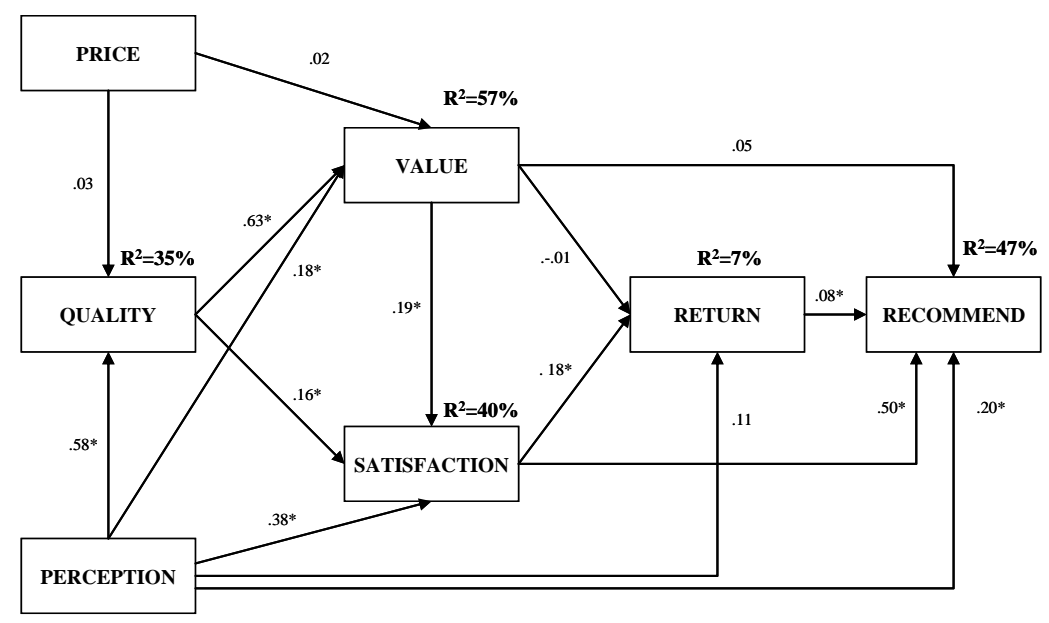

Table 6. Goodness-of-fit indices

\begin{tabular}{cccccccccc}
\hline & $\chi^{2}$ & $d f$ & $p$ & NFI & RFI & IFI & TLI & CFI & RMSEA \\
\hline Model & 14.08 & 5 & $<.015$ & 0.99 & 0.95 & 0.99 & 0.97 & 0.99 & 0.06 \\
\hline
\end{tabular}

Except for five causal paths, all other hypothesized relationships appeared to be statistically significant $\left(p<0.015, d f=5, \chi^{2}=14.075\right)$. Notably, perceived quality, perceived value, and customer satisfaction appeared to have a significant impact on the customers' intent to recommend. The non-significant paths were: a) the relationship of perception of performance with Intent to Return (estimate $=0.11, p=0.07$ ), b) the relationship of price with quality (estimate $=0.03, p=0.42$ ), c) the relationship of price with value (estimate $=0.02, p=0.53), \mathrm{d}$ ) the relationship of value with Intent to return (estimate $=-0.01, p=0.88$ ), and e) the relationship of value with intent to recommend (estimate $=0.05, p=0.21$ ).

A considerable amount of variance was explained for value $(57.5 \%)$, intent to recommend (47\%) and quality (35\%). Furthermore, it was determined that although the model had 5 non-significant paths, it provides a holistic explanation of the factors that influence intent to return and intent to recommend for eco-tourists visiting the Galapagos. Examination of hypotheses 1a, 1b, 1c, 1d and 1e shows that perception of performance is a good indicator of quality, value, satisfaction, and intent to recommend; therefore these hypotheses were accepted. With regards to the path of perception of performance towards intent of return, the relationship was non significant (estimate $=0.11, \mathrm{p}>.05$ ), thus the hypothesis was not supported.

Next, hypotheses $2 \mathrm{a}$ and $2 \mathrm{~b}$ proposed that perceived price will influence perceived quality and value. The results from Figure 2 indicate that both hypotheses are unsupported. This proved different from the previous model (Oh, 1999) which indicated a significant impact of the influence of perceived price on quality and value. It is also interesting to note that $\mathrm{Oh}$ (1999) predicted a negative relationship between perceived price and perceived value.

Hypotheses $4 \mathrm{a}$ and $4 \mathrm{~b}$ anticipated that satisfaction would assist in predicting intent of return and intent to recommend. Both hypotheses were significant $(p>.05)$ and were therefore 
accepted. Hypotheses 5a, 5b and 5c proposed that value would be a good predictor of satisfaction, intent to return and intent to recommend. The results revealed that only one path (value with satisfaction) was significant $(p<.01)$. The other two paths, value with intent to return and value with intent to recommend, were found to be non-significant, $p=0.88$ and $p=0.21$ respectively. Interestingly, value with intent to return was found to be in a negative relationship $(-0.01)$, albeit a weak one. The final hypothesis, 6a, proposed that intent to return $(0.08)$ would be a good predictor of intent to recommend. This path was significant ( $p>0.01)$ and this hypothesis was accepted. The complete stadarized effects are presented in Table 7.

Table 7. Standardized total effects

\begin{tabular}{lcccccc}
\hline & PERCEPTION & PRICE & QUALITY & VALUE & SATISFACTION & RETURN \\
\hline QUALITY & .609 & .027 & - & - & - & - \\
VALUE & .575 & .035 & .618 & - & - & - \\
SATISFACTION & .603 & .010 & .239 & .172 & - & - \\
RETURN & .193 & .002 & .049 & .037 & .196 & - \\
RECOMEND & .545 & .006 & .148 & .132 & .499 & .083 \\
\hline
\end{tabular}

\section{DISCUSSION}

The results from the survey reveal that tourists visiting the Galapagos have similar demographic profiles (education, gender, age) to the typical ecotourists (Fennell, 1990; Kerstetter, Hou \& Lin, 2004; Meric \& Hunt, 1998; Wight, 1996). More than $90 \%$ of the tourists visiting the Galapagos are first time visitors and over $50 \%$ indicated that the main purpose of their trip was ecotourism. Based on these findings, it is likely that the Galapagos Islands are perceived as an iconic destination and are considered a "once in a lifetime experience." On the other hand, it also may mean that ecotourists are loyal only to the activity, and are simply searching for a spectacle and to self-indulge (Urry, 1990). These explanations may indicate the reason for the overwhelming presence of first timers in the demand composition for the Galapagos.

First timers as the driving force of demand to the Galapagos have important implications for destination managers and for the future of ecotourism in the Galapagos. First timers typically have relatively high search costs in their decision-making process to determine the destination they will be choosing. The information sources used by ecotourists prior to their trip imply that there is an opportunity to lower these costs, by way of referrals, trusted tour operators, or the internet. In the Galapagos, local suppliers are clearly in a disadvantageous position because they lack an international presence, a clear brand, and access to the international market. First timers are therefore inclined to buy from tour operators that they know or are referred to.

Because the purpose of this study was to investigate the post-purchase decision-making process among ecotourists, we tested the proposition that price, quality, performance, value, and satisfaction are effective predictors of behavioral intentions as it applies to ecotourists in the Galapagos Islands. First, the study found that price has no significant impact on perceived quality and value. These results agree with the findings of Lindberg and Aylward (1999), suggesting that prices in the Galapagos may be inelastic. At the same time, the variety of 
activities experienced by visitors indicates that tourist consumption in the Galapagos is commercialized and structured (Lindberg, 1998). The high numbers of visitors who purchased a tourism package $(75 \%)$ can undermine the ability to make local economic linkages reflected in the tourism value chain (Lindberg and Aylward, 1999).

Second, value is influenced largely by quality and perception of performance. Therefore, it is recommended that tourism organizations and service providers capacitate and inform local communities about the importance of offering quality products and services as a strategy to avoid compromising the perception of value. Although value has no direct effect on the intention to revisit or recommend, its impact on satisfaction can influence future behavior, especially the intent to recommend.

Third, for ecotourism in the Galapagos to succeed, the study suggests that government officials pay special attention to managing the nine specific performance attributes identified in the study (for example, see Baker \& Crompton, 2000; Chan \& Baum, 2007; Page \& Dowling, 2002). The ecotourists' perception of a destination's performance plays a vital role in explaining quality, satisfaction, value, and intent to recommend. Maintaining local environmental quality appears as a key area of concern- this area received the one of the lowest scores among the visitors - because the survival of this pristine archipelago highly depends on conserving the ecosystem. For the Galapagos, generating revenue for the destination and local communities is essential, but this should be done without compromising the conservation of the fragile ecosystem, which makes the experience possible in the first place.

The lack of explanatory power of satisfaction and value on the intent to return, together with a higher likelihood to recommend than to return, suggest that for ecotourists, loyalty is more a function referral, which consequently may be important for the development and sustainability of the tourism sector in the Galapagos.

\section{Managing "Word Of Mouth" in the Galapagos Islands.}

The importance of referral word of mouth (WOM) for the Galapagos is two dimensional. Referral WOM seems important not only before the purchase (input) but after the purchase (output) (Buttle, 1998). Input WOM is considered an essential source of pre-purchase information and is considered more important than advertising in raising awareness about a product. The positive relationship between high levels of satisfaction and perception of the destination on the intention to recommend unveils new opportunities for the development of sustainable tourism in the Galapagos. Inopportunely, the dissemination of information about the Galapagos is controlled by travel agents, tour operators, and the internet; while paradoxically, only $34 \%$ of the ecotourists received input WOM from friends and relatives. Thus, demonstrating input WOM in the Galapagos is not completely independent from corporate influence. This research provides empirical evidence which demonstrates that the sustainability of local business and the environment in the Galapagos could rely on the DMO's ability to influence and manage WOM. This particular organization has the opportunity to persuade local business to participate in a comprehensive WOM referral program. Figure 3 depicts various 
Figure 8. Influencing \& Managing WOM in the Galapagos Islands

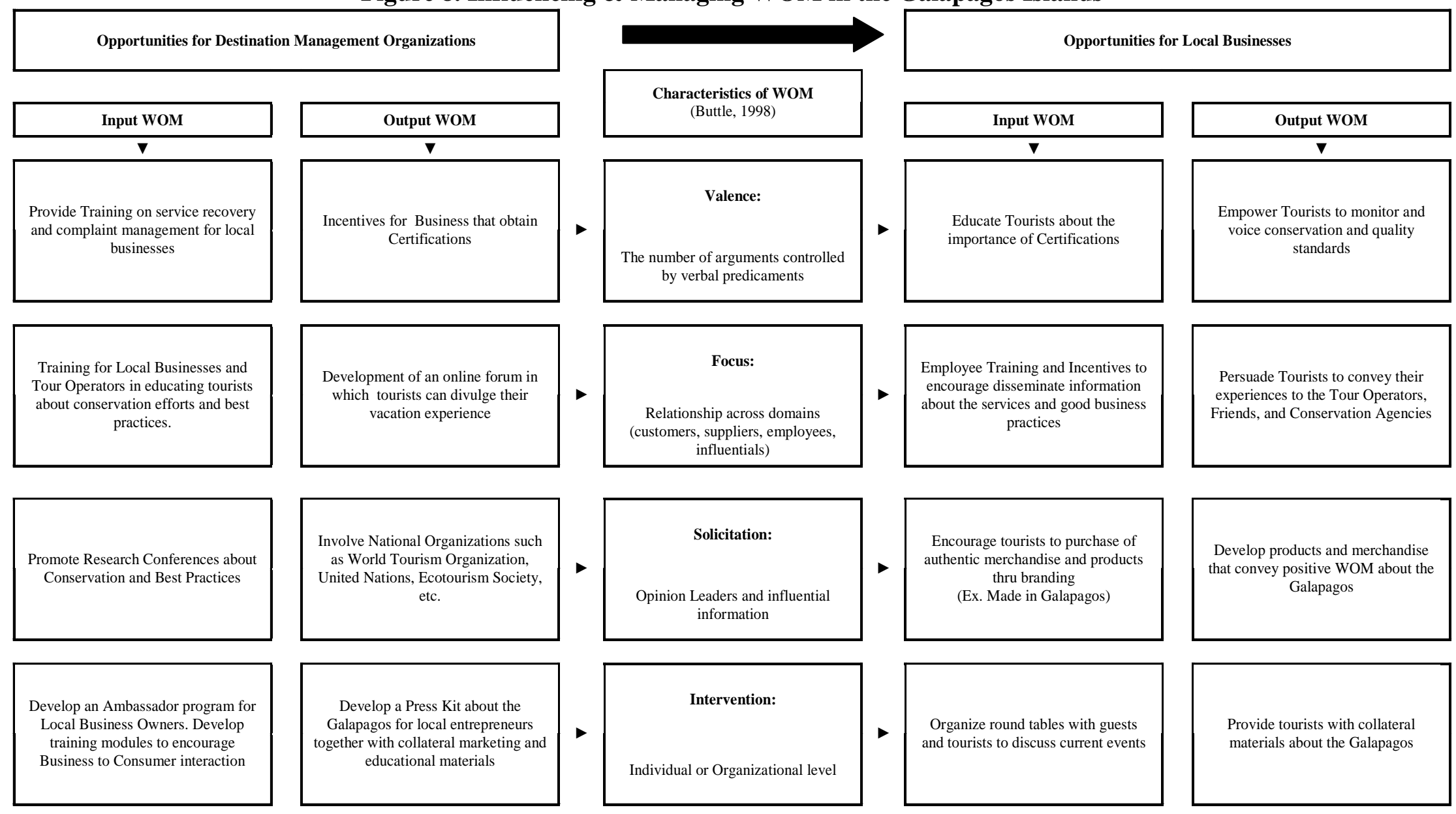


strategies that can help the Galapagos to cope with four specific characteristics of WOM; valence, focus, solicitation, and intervention purchase (Buttle, 1998).

First, verbal predicaments from tourists can be managed by developing training programs that focus on service recovery and complaint management. Local business should be encouraged to obtain certifications that not only educate, but empower tourists to monitor conservation and quality standards. Secondly, the development of relationships through WOM is critical for the destination and the small entrepreneur (Stokes \& Lomax, 2002). Networking with customers, suppliers, and employees should encourage the sharing of information with regards to services and good business practices that consider the environment and conservation. Consequently, tourists can be persuaded to convey their experiences to the tour operators, Friends, and conservation agencies.

Thirdly, DMO's must manage the solicitation of WOM by opinion leaders and the availability of influential information. Research conferences about conservation and best practices should provide tourist and potential visitors with authoritative information from influential leaders. Local entrepreneurs also should be encouraged to provide and sell authentic products and merchandise from the Galapagos, thus conveying positive WOM with influential information. Lastly, WOM intervention must be managed by both private and public entities. At the organizational level, the DMO's can influence WOM by developing a press kit about the Galapagos, which together with an ambassador program can help foster business to consumer interaction. For example, local business can conduct round table meetings with their guests by discussing current events and providing collateral materials about the Galapagos.

These suggestions should help promote the discussion about future research regarding the impact of WOM for ecotourism destinations. In the case of Galapagos, better understanding of WOM communications can help manage and reduce the impacts from first time visitors.

The impact of first timers demand on sustainability

The findings of the study also imply a wider challenge to sustained demand than merely marketing aspects. Effects of sustained demand also have implications for sustainability. The debate about the definition of the sustainability is intense and inconclusive. But there are two salient points in this debate, namely that sustainability refers to conservation and protection of the environment, while portending that the benefits of tourism should accrue to the local population. The debate does not clarify whether these two objectives are consistent with each other or that they may be mutually exclusive.

This debate becomes problematic when considering the importance of environmental quality on the Galapagos product. The quality of the experience of the tourists is directly related to the quality of the environment. The potential degradation of the natural assets in the Galapagos Islands reduces the quality of the most important component of the tourism product, and consequently diminishes the viability of the destination. The environmental quality has been singled out by the tourists visiting the Galapagos Islands as their second greatest concern. The study reveals that for respondents local environment quality had the lowest mean after accessibility. 
This perception combined with the pervasive presence of First Timers in the Galapagos should be reason for concern.

First timers as the most pervasive segment in the Galapagos demand vector could be a daunting challenge to destination managers. First timers are in general defined as individuals having incomplete information about a product in the market place. Facing an intangible product such as tourism, which can be inspected only after purchase, the tourists inevitably will seek information from accessible and trusted sources. These sources overwhelmingly are the international tour operators. In the case of the Galapagos, $75 \%$ of all transactions take place through these tour operators. This figure suggests that little of the revenue from these transactions enters the local economy and benefits the local population, and it may even lead to an economic loss.

This situation could become a powerful incentive for agents or stakeholders to lobby for shifting the benefits of tourism to actors inside the local economy. The effects of this shift and its subsequent multiplier effects could have larger implications, however, for the preservation of the fragile ecosystem than demand expansion or sustained demand. The multiplier effect of the perception of receiving relatively little revenue from tourism could be quite large in a semiclosed economy, such as the Galapagos Islands.

As Taylor, Dyer, Stewart, Yunez-Naude, and Ardila (2003) pointed out, tourism in the Galapagos stimulates the economy by increasing the demand of both tourists and local population who are linked to tourism, thereby increasing the demand for labor. The constrained labor supply will lead to migratory pressures from the mainland. In addition, the increase demand could stimulate environmentally sensitive production activities such as processing and sale of drinking water, fishing, agriculture and natural resource extraction.

This situation poses the difficult challenge of alignment of the objectives of preservation of natural assets while providing benefits to the locals at a nature-based destination. For example, increasing local participation in the transaction with the tourists (at the expense of international tour operators) by shifting the benefits of tourism to actors inside the economy could imply much larger multiplier effects thereby jeopardizing the conservation objectives.

There is another negative implication of the pervasive nature of first timers. Suppliers at a destination are aware of the possible transient nature of consumption of first timers, which is a salient feature of tourism demand to the Galapagos. This could be a strong incentive for suppliers to deliver quality service at a minimum, thereby affecting the level of satisfaction of the tourists, and consequently, decreasing the probability they would recommend the destination to other potential tourists.

Providers must contribute resources for the provision and maintenance of the natural assets while individual incentives could foster individuals to free-ride on the provision activities of others. This situation could lead to environmental degradation instead of protection. The study found that quality has a significant impact on the perception of value of the product and the level of satisfaction. This means that destination managers should safeguard the level of sustained delivery of quality by local suppliers. 
How can this be achieved under the condition of partially (incomplete) informed customers? Previously, the study highlighted the importance of WOM because first timers to the Galapagos are likely to recommend the destination. Communication strategies are important under this condition. WOM could arrest the condition of incomplete information because some tourists may know the quality of the destination based on the recommendation of the first timers. Destination managers should stimulate the WOM to secure a consistency in the delivery of quality and to stimulate honesty of the agents at the destination.

Another way is to make suppliers aware of the complementary nature of the delivery of the tourism product by indicating the positive externalities accruing from cooperation and protecting the environment. A discussion of the three possible coordination modes, such as government intervention, privatization of the resources or the voluntary engagement of agents or stakeholders to solve a common problem is beyond the scope of this study.

In conclusion, destination managers at the Galapagos Islands should strike a delicate balance: stimulate WOM of first timers not only to ensure sustained demand to the Galapagos but to ensure quality of the environment and to make providers aware of the benefits of internalizing positive externalities of sustained demand. On the other hand, this balance also includes managing this sustained demand while ensuring that the economic multiplier effects are kept in check. Shifting benefits to actors within the local economy could be as dangerous to stimulating demand in the case of the sustainability of the Galapagos Islands.

\section{REFERENCES}

Ayala, H. (1995). From quality product to ecoproduct: Will fiji set a precedent? Tourism Management, 16(1), 39-47.

Backman, S., Petrick, J., \& Wright, B. A. (2001). Management tool and techniques: An integrated approach to planning. The Encyclopedia of Ecotourism, 451-477.

Baker, D. A., \& Crompton, J. L. (2000). Quality, satisfaction and behavioral intentions. Annals of Tourism Research, 27(3), 785-804.

Baloglu, S., Pekcan, A., Chen, S. L., \& Santos, J. (2003). The relationship between destination performance, overall satisfaction, and behavioral intention for distinct segments. Journal of Quality Assurance in Hospitality \& Tourism, 4(3/4), 149-165.

Bentler, P. M. (1989). Eqs structural equations program manual. Los angeles: Bmdp statistical software: Inc.

Bitner, M. J. (1990). Evaluating service encounters: The effects of physical surroundings and employee responses. Journal of Marketing, 54(2), 69-82.

Blamey, R. K. (1997). Ecotourism: The search for an operational definition. Journal of Sustainable Tourism, 5(2), 109-130.

Boo, E. (1990). Ecotourism: The potentials and pitfalls: Country case studies. Washington DC:World Wildlife Fund.

Browne, M. W., \& Cudeck, R. (1993). Alternative ways of assessing model fit. Testing structural equation models, 136-162.

Buckley, R. (1994). A framework for ecotourism. Annals of Tourism Research, 21, 661-669.

Burton, R. (1998). Maintaining the quality of ecotourism: Ecotour operators' responses to tourism growth. Journal of Sustainable Tourism, 6(2), 117-142.

Buttle, F. A. (1998). Word of mouth: Understanding and managing referral marketing. Journal of Strategic Marketing, 6(3), 241-254.

Carman, J. M. (1990). Consumer perceptions of service quality: An assessment of the servqual dimensions. Journal of Retailing, 66(1), 33-55. 
Ceballos-Lascurain, H. (1987). The future of ecotourism. Mexico Journal, 1, 13-14.

Chan, J. K. L. (2007). Motivation factors of ecotourists in ecolodge accommodation: The push and pull factors. Asia Pacific Journal of Tourism Research, 12(4), 349-364.

Chan, J. K. L., \& Baum, T. (2007). Ecotourists'perception of ecotourism experience in lower kinabatangan, sabah, malaysia. Journal of Sustainable Tourism, 15(5), 574.

Cronin, J. J., Brady, M. K., \& Hult, G. T. M. (2000). Assessing the effects of quality, value, and customer satisfaction on consumer behavioral intentions in service environments. Journal of Retailing, 76(2), 193-218.

Cronin, J. J., \& Taylor, S. A. (1994). Servperf versus Servqual: Reconciling performance-based and perceptions-minus-expectations measurement of service quality. Journal of Marketing, 58(1), 125-131.

Danaher, P. J., \& Arweiler, N. (1996). Customer satisfaction in the tourist industry: A case study of visitors to new zealand. Journal of Travel Research, 35(1), 89.

Day, G. S. (1969). A two-dimensional concept of brand loyalty. Journal of Advertising Research, 9(3), 29-35.

Deng, J., King, B., \& Bauer, T. (2002). Evaluating natural attractions for tourism. Annals of Tourism Research, 29(2), 422-438.

Donohoe, H. M., \& Needham, R. D. (2006). Ecotourism: The evolving contemporary definition. Journal of Ecotourism, 5(3), 192-210.

Duffy, R. (2002). A trip too far: Ecotourism, politics, and exploitation. London: Earthscan.

Eagles, P. F. J. (1992). The travel motivations of Canadian ecotourists. Journal of Travel Research, 31(2), 3.

Eagles, P. F. J., \& Cascagnette, J. W. (1995). Canadian ecotourists: Who are they. Tourism Recreation Research, 20(1), 22-28.

Epler, B. (1993). An economic and social analysis of tourism in the galapagos islands. Coastal Resources Center. University of Rhode Island. Narragansett, RI.

Fennell, D. A. (2001). A content analysis of ecotourism definitions. Current Issues in Tourism, 4(5), 403-421.

Fennell, D. A. (2003). Ecotourism: An introduction. London: Routledge.

Fennell, D. A., \& Eagles, P. F. J. (1990). Ecotourism in costa rica: A conceptual framework. Ecoturismo en costa rica: Un marco conceptual. Journal of Park and Recreation Administration., 8(1), 23-34.

Finn, M., Elliott, M., \& Walton, M. (2000). Tourism and leisure research methods: Data collection, analysis and interpretation. Harlow: Longman.

Gallarza, M. G., \& Gil-Saura, I. (2006). Value dimensions, perceived value, satisfaction and loyalty: An investigation of university students' travel behaviour. Tourism Management, 27(3), 437-452.

Hu, L. T., \& Bentler, P. M. (1998). Fit indices in covariance structure modeling: Sensitivity to underparameterized model misspecification. Psychological methods, 3(4), 424-453.

International Ecotourism Society. (2006). Fact sheet: Global ecotourism: Canopy Development.

Ingram, C. D., \& Durst, P. B. (1989). Nature-oriented tour operators: Travel to developing countries. Journal of Travel Research, 28(2), 11.

Jacoby, J., \& Chestnut, R. W. (1978). Brand loyalty: Measurement and management: New York: Wiley.

Kerstetter, D. L., Hou, J. S., \& Lin, C. H. (2004). Profiling taiwanese ecotourists using a behavioral approach. Tourism Management, 25(4), 491-498.

Khan, M. M. (1997). Tourism development and dependency theory: Mass tourism vs. Ecotourism. Annals of Tourism Research, 24(4), 988-991.

Khan, M. M., \& Su, K. D. (2003). Service quality expectations of travellers visiting cheju island in korea. Journal of Ecotourism, 2(2), 114-125.

Lee, C. K. (1997). Valuation of nature-based tourism resources using dichotomous choice contingent valuation method. Tourism Management, 18(8), 587-591. 
Lee, W. H., \& Moscardo, G. (2005). Understanding the impact of ecotourism resort experiences on tourists' environmental attitudes and behavioural intentions. Journal of Sustainable Tourism, 13(6), 546-565.

Lindberg, K. (1998). Economic aspects of ecotourism. Lindberg, K., Wood, M E FIX.

Lindberg, K., \& Aylward, B. (1999). Price responsiveness in the developing country nature tourism context: Review and costa rican case study. Journal of Leisure Research, 31(3).

McKercher, B. (1993). Some fundamental truths about tourism: Understanding tourism's social and environmental impacts. Journal of Sustainable Tourism, 1(1), 6-16.

McKercher, B. (1998). The politics of tourism and conservation organisations: The case of the victorian national parks association 1952-1996. Progress in Tourism and Hospitality Research, 4(2), 141.

Meric, H. J., \& Hunt, J. (1998). Ecotourists'motivational and demographic characteristics: A case of north carolina travelers. Journal of Travel Research, 36(4), 57.

Murphy, P. E., \& Pritchard, M. (1997). Destination price-value perceptions: An examination of origin and seasonal influences. Journal of Travel Research, 35(3), 16.

New Scientist Magazine. (2007). Rampant tourism leaves Galapagos in big trouble. Reed Business Information, 194(2600), 1.

Oh, H. (1999). Service quality, customer satisfaction, and customer value: A holistic perspective. International Journal of Hospitality Management, 18(1), 67-82.

Oliver, R. L. (1980). A cognitive model of the antecedents and consequences of satisfaction decisions. Journal of Marketing Research, 17(4), 460-469.

Oliver, R. L. (1997). Satisfaction: A behavioral perspective on the consumer: New York: McGraw Hill.

Oppermann, M. (1997). First-time and repeat visitors to new zealand. Tourism Management, $18(3), 177-181$.

Oppermann, M. (2000). Tourism destination loyalty. Journal of Travel Research, 39(1), 78.

Otto, J. E., \& Ritchie, J. R. B. (1996). The service experience in tourism. Tourism Management, 17(3), 165-174.

Page, J. S., \& Dowling, R. K. (2002). Ecotourism: Themes in tourism. Essex: Pearson Education.

Palacio, V., \& McCool, S. F. (1997). Identifying ecotourists in belize through benefit segmentation: A preliminary analysis. Journal of Sustainable Tourism, 5(3), 234-243.

Parasuraman, A., Zeithaml, V. A., \& Berry, L. L. (1988). Servqual: A multiple-item scale for measuring consumer perceptions of service quality. Journal of Retailing, 64(1), 12-40.

Peter, J. P., Churchill, J. G. A., \& Brown, T. J. (1993). Caution in the use of difference scores in consumer research. Journal of Consumer Research, 19(4), 655.

Petrick, J. F. (2004). Are loyal visitors desired visitors? Tourism Management, 25(4), 463-470.

Pizam, A., Neumann, Y., \& Reichel, A. (1978). Dimensions of tourist satisfaction with a destination area. Annals of Tourism Research, 5(3), 314-322.

Powell, R. B., \& Ham, S. H. (2008). Can ecotourism interpretation really lead to proconservation knowledge, attitudes and behaviour? Evidence from the galapagos islands. Journal of Sustainable Tourism, In Press.

Ryan, C., Hughes, K., \& Chirgwin, S. (2000). The gaze, spectacle and ecotourism. Annals of Tourism Research, 27(1), 148-163.

Ryel, R., \& Grasse, T. (1991). Marketing ecotourism in whelan. Nature Tourism Island Press, Washington, DC, 164-186.

Saarinen, J. (2005). Tourism in the northern wildernesses: Wilderness discourses and the development of nature-based tourism in northern finland. Nature-based Tourism in Peripheral Areas: Development or Disaster, 36-49.

Sánchez, J., Callarisa, L., Rodríguez, R. M., \& Moliner, M. A. (2006). Perceived value of the purchase of a tourism product. Tourism Management, 27(3), 394.

Shackley, M. (1996). Wildlife tourism: Thomson Learning EMEA.

Sharpley, R. (2006). Ecotourism: A consumption perspective. Journal of Ecotourism, 5(1), 7-22. 
Sirakaya, E. (1997). Attitudinal compliance with ecotourism guidelines. Annals of Tourism Research, 24(4), 919-950.

Starmer-Smith, C. (2004). Eco-friendly tourism on the rise. Daily Telegraph Travel, 4.

Stevens, B. F. (1992). Price value perceptions of travelers. Journal of Travel Research, 31(2), 44.

Stokes, D., \& Lomax, W. (2002). Taking control of word of mouth marketing: The case of an entrepreneurial hotelier. Journal of Small Business and Enterprise Development, 9(4), 349-357.

Szymanski, D. M., \& Henard, D. H. (2001). Customer satisfaction: A meta-analysis of the empirical evidence. Journal of the Academy of Marketing Science, 29(1), 16.

Taylor, S. A. (1997). Assessing regression-based importance weights for quality perceptions and satisfaction judgements in the presence of higher order and/orinteraction effects. Journal of Retailing, 73(1), 135-159.

Taylor, J. E., Dyer, G. A., Stewart, M., Yunez-Naude, A., \& Ardila, S. (2003). The economics of ecotourism: A galapagos islands economy-wide perspective*. Economic Development and Cultural Change, 51(4), 977-997.

Teas, R. K. (1994). Expectations as a comparison standard in measuring service quality: An assessment of a reassessment. Journal of Marketing, 58(1), 132-139.

Urry, J. (1990). The tourist gaze: Leisure and travel in contemporary societies: Sage Publications.

Wall, G. (1993). Ecological reserves and protected areas: The challenge of ecotourism. Paper presented at the Seminar on the Environment of the Academic and Scientific Community of Mexico, Toluca, Mexico.

Watkins, G., \& Cruz, F. (2007). Galapagos at risk: A socioeconomic analysis of the situation in the archipielago. Puerto Ayora, Province of Galapagos, Ecuador: Charles Darwin Foundation.

Weaver, D.B. (2001). Ecotourism: Milton, Qld.:[Great Britain]: John Wiley \& Sons.

Weaver, D. B. (2001b). Ecotourism as mass tourism: Contradiction or reality. Cornell Hotel and Restaurant Administration Quarterly, 42(2), 104-112.

Whelan, T. (1991). Nature tourism: Managing for the environment. Washington, D.C.

Wight, P. A. (1996). North american ecotourists: Market profile and trip characteristics. Journal of Travel Research, 34(4), 2.

Wight, P. A. (1997). Ecotourism accommodation spectrum: Does supply match the demand? Tourism Management, 18(4), 209-220.

Wight, P. A. (2001). Ecotourists: Not a homogeneous market segment. The Encyclopedia of Ecotourism, 37-62.

Williams, N. (2006). Pressure points. Current Biology, 16(10), R343.

Williams, P. W. (1992). A local framework for ecotourism development. Western Wildlands, 18(3), 14-19.

World, Tourism, Organization. (2001). Global forecasts and profiles of market segments. Madrid: WTO.

Yoon, Y., \& Uysal, M. (2005). An examination of the effects of motivation and satisfaction on destination loyalty: A structural model. Tourism Management, 26(1), 45-56.

Zeithaml, V. A. (1988). Consumer perceptions of price, quality, and value: A means-end model and synthesis of evidence. Journal of Marketing, 52(3), 2-22. 